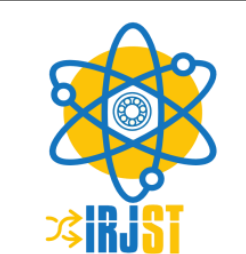

Available online at https://www.irjst.com/

International Research Journal of Science and Technology

ISSN: $2707-3955$

DOI: https://doi.org/10.46378/irjst.2020.010302

\title{
The Performance of Agricultural Cooperatives to Endorse Socio-Economic Development in Ethiopia.
}

\author{
Dr.S.Srinivasan ${ }^{1}$, Dr.B.Barani Sundaram ${ }^{2}$ \\ ${ }^{1}$ Associate Professor, Department of Economics, Bule Hora University, Ethiopia. \\ ${ }^{2}$ Associate Professor, Department of Computer Science, Bule Hora University, Ethiopia
}

\begin{tabular}{lll}
\multicolumn{2}{l}{ Paper Status } & \\
\hline Received & Apr2020 \\
Accepted & $:$ & May 2020 \\
Published & $:$ & Jun 2020
\end{tabular}

\section{Key Words}

Agricultural Cooperatives Agricultural Input Output Marketing

Generating Job Opportunities Performance of primary and secondary cooperatives

\section{Abstract}

Cooperatives in Ethiopia provide assistance mainly agricultural farmers' input and marketing for their produces. Hence, cooperatives are receiving due attention because of their immense contribution to address the challenge of the people with regard to low level of income, unemployment, poor market for agricultural product etc. It is not surprising that the cooperatives have a great role in generating income, providing goods and services at reasonable price to their members goes down to the rural areas and provide employment opportunity to the citizen also. Consequently, cooperatives have a considerable contribution in poverty reduction thereby developing the national economy. Secondary data regarding agricultural inputs distribution in the year 2015/16-2018/19, agricultural output marketing by cooperatives from 2016-2018, cooperatives provide job opportunities, performance of primary and secondary cooperatives -2016/17 has been used to analyze performance of agricultural cooperatives in Ethiopia. Cooperatives represent more than $85 \%$ of the total input supply to the public and the price drop to the public through competitive order on average $10-15 \%$. The cooperatives of the country contribute meaningful employment opportunity and poverty alleviation in the country in the last ten years and Primary and secondary cooperatives undertaking countless work among the members and their capital accumulation is outstanding in the nation.

\footnotetext{
Copyright (C) 2020: Dr.S.Srinivasan, Dr.B.Barani Sundaram. This is an open access distribution, and reproduction in any medium, provided Access article distributed under the Creative Commons Attribution License the original work is properly cited License, which permits unrestricted use.

Citation: Dr.S.Srinivasan, Dr.B.Barani Sundaram. "The Performance of Agricultural Cooperatives to Endorse Socio-Economic Development in Ethiopia.”. International Research Journal of Science and Technology, 1 (3), 199-205, 2020.
}

\section{Introduction}

Cooperatives in Ethiopia provide assistance mainly agricultural farmers' input and marketing for their produces. Cooperatives in Ethiopia is diverse systems and there are different forms of cooperatives are existed as traditional forms of cooperatives such as Debbo, jiggie or wonfel, Equib, Eddir, Mahiber, Senbetie which are giving assistant to the employment in the agriculture, input for production and marketing for its produces. Hence, in developing nations, cooperatives are getting due care because of their enormous role to address the encounter of the

\footnotetext{
* Corresponding Author: Dr.S.Srinivasan

Associate Professor, Department of Economics

Bule Hora University, Ethiopia.

Email: srini.cud@gmail.com
}

community regarding low level of income, joblessness, poor market for agricultural product etc.

It is not astonishing that the cooperatives have a great part in making revenue, giving goods and services at rational price to their members whereas creates employment opportunity to the public of the country. Therefore, cooperatives have a significant role in poverty alleviation of the country.

In Ethiopia, the cooperative movement starts around 1960s for the essential of versatile activities as: 1 . Creating rural credit, 2. Storing and marketing agricultural produces, 3. Giving goods and services for production and consumption to the public and 4 . Increase saving habits. Because of that "Cooperative Societies' Proclamation" was established in the year of 
1974 and promotes commercial crop production in the area of Wollega, Jimma, Agaro, kafa, and Sidamo to earn money and foreign exchange. Several forms of cooperatives created in the year of 1982 as services cooperatives, producer's' cooperatives in Agri and industrial sector, housing cooperatives and savings and credit cooperatives. It's all as much as indulge in catastrophe because of lack of coordination between government and community, misuse of the cooperatives and red tape governmental institutions. Currently, in the movement of cooperatives in Ethiopia has enormous changes and expansion to achieve goals of the members and promotes members act as independent in a democratic way of management.50 percent of GDP and 82 percent of population are depending upon agricultural sector of the country and also the country depends on foreign aid due to low productivity. Hence, cooperatives societies particularly, agricultural cooperatives performance a countless role for the expansion of the Agri sector and thus promote social and economic development of the country.

\subsection{Objectives of the Study}

The core objective of this paper is to understand the performance of agricultural cooperatives in achieving socio economic development in Ethiopia.

\section{Literature Review}

In this section, some authors' views on the performance of the cooperatives in Ethiopia have been reviewed to analyze the recital of the cooperatives.

It was explained that Ethiopia has the strong network for organic coffee and this practice could use for chance to marketing also. This assure appropriate price for livestock of the farmers and other people and a supportable livelihood procedure [1].

Smallholders' farmers produce small number of agricultural products and they brought small amount of the produce to market and it covers their regular expenses. After establishment of the cooperatives in Ethiopia since 1960s, that enhance the development of smallholder's farmers and other communities specially SNNPR region in Ethiopia [2].

Agricultural cooperatives in Ethiopia faced challenges like lack of sense of ownership, low follow up and control system by the government, lack of commitment, mistrust and awareness by the members of the cooperatives, management committee's minute knowledge about cooperatives hence failure of the management in the governance of the cooperatives. And the agricultural cooperatives are still to improve for the development of the society [3].

The linking agricultural cooperatives have an optimistic impact on the welfare of smallholder farmers. Still, the analysis also indicates that agricultural cooperative membership has a mixed impact on welfare among its members [4].

The impact of modern cooperatives has speedily improved and certainly paid to community development, some burden and trials still remain being fixed in the Socio-economic sceneries and there are gradual benefits for the members of the cooperatives in the present Ethiopia and the higher communal converts important that earns policymakers' care on the development of the cooperatives [5].

Development of Co-operative in Ethiopia has been sturdily disposed that gives the motivation to change inputs of the agricultural farmers into commercialization of their products. Hence, the effect of commercialization on farmer welfare is still questionable. Both the institutional situation and the internal regulations have the struggle to adjusting for changes in the economic conditions of the farmers and members of the cooperative societies [6].

Ethiopian cooperatives have paid a major share in the country's economic development and also supportive their members by offering various goods and services, and lots of assistances like food security, income hike, enhancing standard of living and communal contribution. Besides, 15 to 29.68 percentage of job creations and 28,032.29 to 122,297.7-birr annual income for per cooperatives. Based on the review of literature, the paper further doing analysis of performance of cooperatives in Ethiopia in the next topics [7].

\section{Methodology of the Study}

The paper is organized and prepared with secondary data which obtained from Federal Cooperative Commission Report. (2018/19)

\subsection{Data Analysis and Presentations}

This section presents the result obtained from analysis of data and the explanation of all information collected under the major areas of study namely: the contribution of cooperative for socio economic development, performance of primary and secondary (union) cooperatives, the profit making condition of agricultural cooperatives and regional distribution of assets of cooperatives (primary and unions).

\subsection{Contribution for Socio Economic Development}

Cooperatives have provided to be a key structural form in construct new models to fight communal exclusions and poverty for instance food security ensures in Ethiopia by small agricultural land holders and this sector has a very low capacity and incapable to meet the demands of raw materials for food production industries. It could be recovered by cooperative institutions only. These cooperatives have structural 
problems and enhance the development of rural and agricultural farmers. The performances of agricultural cooperatives are farm producer's work with the cooperatives, purchase from rural small-scale producers and farmers and providing input for the production besides working as marketing for the produces. These Farmer's cooperatives and union offer a chance to improve the bargaining power of agricultural producers in both the buying of essential inputs and sale of farm products. As a commercial society, they familiar part of the private sector and have started cooperating with their associates.

\subsection{Agricultural Input Output Marketing}

In rural development policies and strategies of Ethiopia, the character of that cooperatives play is so significant, in the sense that cooperatives are commercial administrations possessed and managed by the farmers themselves. Cooperatives represent the majority of the farmers, since it is very difficult and highly costly to try to realize the market functions on individual farmer's basis and they systematize agricultural input output marketing. If cooperatives distribute major agricultural commodities directly to the farmer, the channels will be shortened; price decreases, thus, increasing the income (benefit) of farmers.

Agricultural marketing and supply cooperative are most important types of cooperatives in Ethiopia, which are principal in rural areas. They are earnings for farmers who want to purchase inputs in bulk and cooperatively sale their crops in order to increase their trading power. The share in chemical, fertilizers, improved seed supply, and purchase such collectives reach more than $85 \%$ of the total annually distributed. For instance, we can see the annual agricultural inputs distribution in figure below.

Figure 1, shows that the agricultural input distribution in the year 2015/16-20018/19. As the graph, the agricultural inputs distribution increases along the cooperatives, the agricultural output in terms in terms of quintals increased in this year's (2015/1620017/18), the cooperatives total usage of input fertilizer is 2,821,048 of fertilizers which obtained from domestic export purchases. The export purchases [imports] fertilizers in these years are 50,000 quintals of fertilizers which includes the chemicals of DAP and urea. the agricultural cooperatives also domestic fertilizers which include manures and animal wastes. The import usage of fertilizer is lower than that of the domestic fertilizers. This so because the import fertilizers so costly due to import tax charged by the imports (countries it itself) and the depreciation of our currency with compare to other countries which needs more to purchase it. Presently, in different part of the country's regions most of the cooperatives adopt the natural fertilizers to increase the productivity of agriculture and minimize the use of import fertilizers. Form the graph; we observe that the use of improved seeds from 2015/16-18/19 G.C and it has increased to further 2018/19. As it is pointed out, the total usage of improved seeds in these years was 175,318 quintals of seed increased to 182,326 quintals. These improved seeds obtained from import and purchase form other farmers within the country. The cooperatives farming in the country still uses foreign improved to increase the productivity of agriculture. The most commonly used improved seeds in the country's cooperatives include beans, wheat and cereal crops. These improved seeds are small with compared to the country's availability of seeds. However, because of different reasons such as increasing awareness about the increasing use of different domestic seeds by adopting (following) import substitution mechanism. Now a days, most cooperatives use domestic seeds in the country rather than purchase from abroad to facilitate the input requirement timely and effectively.

Therefore, in order to encourage the productivity of cooperatives, the use domestic seed, fertilizers and other agricultural inputs is sturdily worthwhile. Thus, it advances efficiency of farms cooperatives through appropriate cultivation of the land and the cost incurred by cooperatives could be lesser and complement to the nation's economy.

Agricultural cooperatives also play important role involve creation by accessing the product of smallscale producers to terminal market in the year from 2007-2018. For instance, we can see their agricultural marketing in between producers and consumers where purchasing outputs from small-scale farmers, they try to sell to the local consumers and export cash crops to the world market as shown in the table 1 .

The table 1 shows that agricultural output marketing by cooperatives from 2016/17-2017/18. As definite in the table 1, the cooperative farmers are important role as middle men to endorse agricultural market in the country. The cooperative farmers buying the agricultural output from the domestic producers and sell to the final clients in the country and also export produces, in the case of coffee export to other nation. From the table 1, we could see that the agricultural market output in three consecutive years (2016-18) is showing marvelous development by cooperative farmers. In agricultural output marketing cereal crop has huge figure of participants, which are 1300 primary participants and 48 union participants. Next to this crop, coffee export stands the second in terms of the number of participants, which is 339 primary cooperatives and 4 union participants. In the eight types of agricultural outputs purchased by 


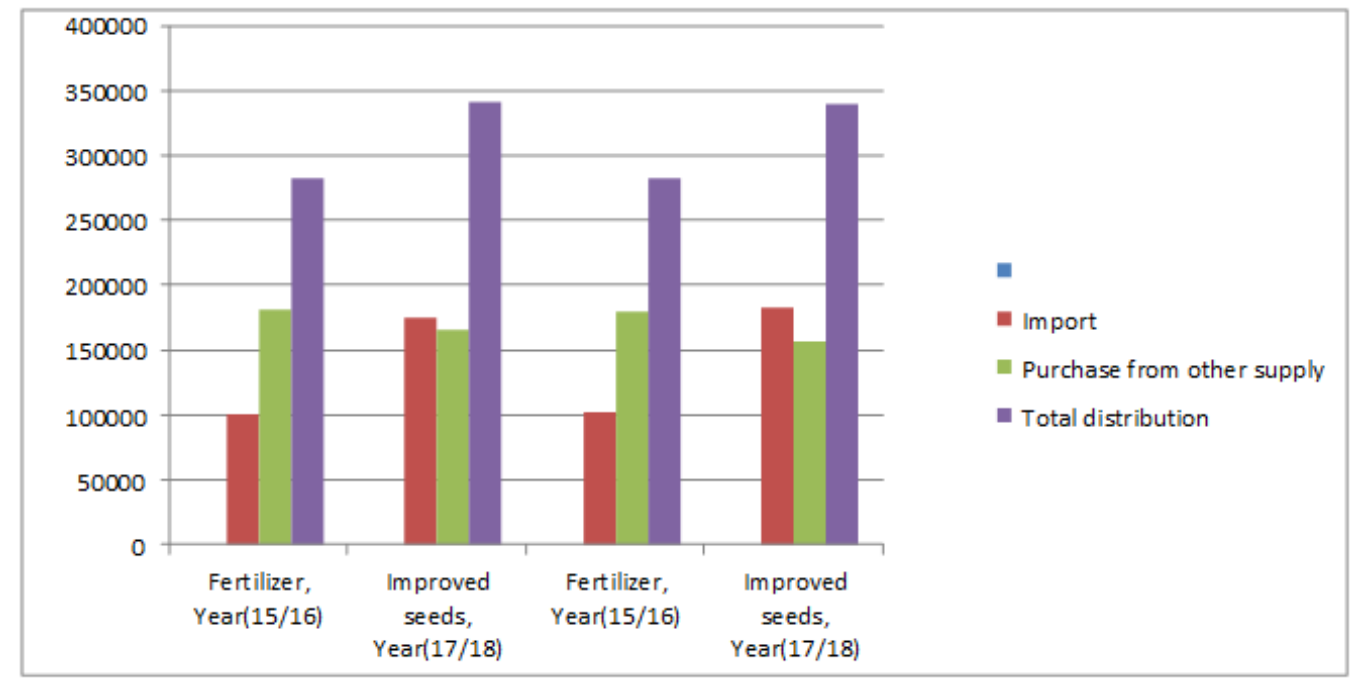

Figure 1: Agricultural Inputs Distribution in the Year 2015/16 - 2018/19 (Units in quintal) Source: Federal Cooperative Commission. (2015/16-2018/19)

Table 1: Agricultural output marketing by cooperatives from 2016-2018

\begin{tabular}{|c|c|c|c|c|c|c|c|c|}
\hline \multirow[b]{2}{*}{ Output } & \multirow[b]{2}{*}{$\begin{array}{l}\text { Primary } \\
\text { participant }\end{array}$} & \multirow[b]{2}{*}{ Union } & Purchase & Sale & Purchase & Sale & Purchase & Sale \\
\hline & & & Year 2016 & $\begin{array}{l}\text { Year } \\
2016\end{array}$ & Year 2017 & $\begin{array}{l}\text { Year } \\
2017\end{array}$ & Year 2018 & Year 2018 \\
\hline Cereal output & 1300 & 48 & 948662 & 580922 & 1082620 & 964960 & 16945 & 1600000 \\
\hline $\begin{array}{l}\text { Vegetable and } \\
\text { fruit }\end{array}$ & 12 & 22 & 532571 & 530758 & 640320 & 622300 & 720300 & 700000 \\
\hline Spices & 23 & 5 & 2979 & 2678 & 3600 & 3400 & 4500 & 4200 \\
\hline Cotton & 25 & 1 & 18851 & 1600 & 1000 & 900 & 300 & 1 \\
\hline Wool & 1 & 1 & 515 & 515 & 700 & 7000 & 8200 & 8000 \\
\hline Coffee export & 339 & 4 & 18083 & 18083 & 19000 & 19000 & 24000 & 19000 \\
\hline Milk & 24 & 1 & 220830 & 209441 & 240700 & 130400 & 25000 & 240000 \\
\hline Livestock & 15 & 1 & 27519 & 27507 & 28300 & 28300 & 29500 & 28900 \\
\hline
\end{tabular}

$*$ (Units in quintal)

Table 2. Cooperatives Provide Job Opportunities (Number of Peoples)

\begin{tabular}{llllll}
\hline Regions & $2010 / 11$ & $2011 / 12$ & $2012 / 13$ & $2013 / 14$ & $2014 / 15$ \\
\hline Amhara & 1041 & 1793 & 2000 & 2100 & 2200 \\
Tigray & 157 & 771 & 1030 & 1500 & 2000 \\
Oromia & 807 & 2522 & 3500 & 4000 & 4100 \\
SNNPR & 1045 & 1766 & 2400 & 2600 & 2700 \\
Total & 3050 & 6852 & 8930 & 10200 & 11000 \\
\hline
\end{tabular}

Source: Federal Cooperative Commission (2006/7-2013/14)

cooperatives, coffee crop has the principal demand crop export to other countries. While export of the coffee, the cooperative farmers are beneficial by generating adequate revenue. They purchase of coffee from the local farmers at equivalent price and organize export. Consequently, they generate optimistic monetary revenue; it enables them to rise their attitude in joining international trade for other supplies transaction. Nonetheless, in agricultural output marketing by cooperatives, few agricultural outputs may not have enough demand in these consecutive years for instance cotton. As detailed above, the demand for cotton crop is falling from year to years.
The reason is cooperative farmers have discouraged attitude of export /domestic sale of cotton. Cotton purchase from the local farmers decline as shown in the table 1 .

The cooperative farmers appreciated the goal of attaining revenue margin is diverse while they transaction at home and outside the country. When they do trade within the nation, they sell their output at equivalent market prices which is essential for both producers and consumers in the country, so the price of output is reasonable in regarding the consumers' revenue. Here, both producers and consumers are equally beneficial and leads to social welfare extension in the country while they do trade outside the country, 
they charge higher price for the produces that permits them making optimistic economic income. Therefore, cooperatives output marketing is depending upon the local revenue of the people that is people could get profit or not. Then, they are market intermediation in the home marketing by supplying the agricultural output to consumers in the community.

Table 2 shows that the regional employment distribution of cooperatives in the different regions. As stated in the table 2, it was the total of 3050 peoples had get access to employment opportunities in the year of 2010/11 where SNNPR had high level of job provider next to Amhara regions (1041). In the year 2011/12, the contribution of agricultural cooperatives in creating employment opportunity was increased by double amount. It was the total of 6852 peoples who have got employment opportunity in the country. In this year, the Oromia regional state was the first region (2522) than other reigns in employment creation opportunity. The Amhara regional state stands the second in this year. In the year 2012/13, the country had got the total of 8930 individuals in employment opportunity in the regions of Amhara, Tigray, Oromia and Southern Nation Nationalities Peoples and Region (SNNPR). In this year, the Oromia region (3500) was the first in creating job opportunity for large groups of people and the next regions was SNNPR with 2600 who got job opportunity. In the year of 2014/15, the country has got the total 10,200 individuals in employment opportunity. The Oromia regional state (4100) was the leading region in the country in providing employment opportunity and next region was SNNPR with 2700 that employed. Hence, from the year 2010/11-2014/15 (five consecutive years), the country had got meaningful number of individuals who employed and capable of lead their life selfsufficiently and contribute constructive role in poverty alleviation program of the country.

\subsection{Performance of primary and secondary cooperatives}

The performance of agricultural cooperatives shows important development from year to year in terms of creation of capital accumulation of members and types of cooperative societies in the country such as primary and secondary cooperatives.

\subsubsection{Performance of Primary Cooperative}

There are primary cooperatives working in the country such as multiple agricultural, forest development, fruit and vegetable cooperatives, Gum and insects, irrigation cooperatives, dairy, fishery, honey, coffee, livestock, and chat. These cooperatives contribute major role in the generation of employment and marketing for the produces. The table -4 shows that performance of primary cooperatives in the year 2016/17.

The table 3 shows the status of primary cooperatives society's form 2011/12-2016/17 and eleven primary agricultural cooperatives are working with the people of the country. Among the primary cooperatives, multipurpose agricultural cooperatives societies having the largest members i.e. 47,813,442 total members while the chat cooperative societies having the small number of members which are 104 total members and it has no female members. The total capital of the eleven cooperatives are 1,003,572,293 birr where Multipurpose Agricultural cooperative shares highest is 753,556,364-birr because of largest number of members in this cooperative society whereas the chat cooperative society contributes meager share among the all cooperatives is 9660 birr and the reason is the smallest members in this society. While assessing capital per total member, Dairy cooperatives has higher is 8843.5 birr and it expresses that milk producing has decent earing in Ethiopia and it follows by Gum and insects' cooperatives which is 4138.07birr capital per total members. The lowest capital per total members is Multi-purpose Agricultural Society is 15.76 birr and reason is largest members' shares lowest money in this society.

The table 4 shows that the position of secondary cooperatives forms 2011/12-2016/17. As it is stated, the largest members of the cooperatives is Grain and Marketing cooperatives which is 3392 due to the highest members of the cooperatives, it has highest capital per member also which is 117999.15 birr and it follows by coffee in the member which is 467 and the capital per member is 280324.9 birr. The lowest members and capital per member are honey and forestry which are having 15 and 13 respectively among seven secondary cooperatives. While considering capital per total member share, vegetable and fruit cooperatives society shares the highest amount to their members which is $506,844.8$ birr. The second highest capital per total member is grain and marketing which is $117,999.15$ capital birr whereas the honey cooperatives society contributes the least capital per total members among others which is $22,669.8$ birr. Hence, we could see that capital surplus per total members of the cooperative's society is fewer is not reasonable but the share should be rational to the all members of a society which can see from the grain and marketing cooperative society where the share to per members of the society is beneficial and the other societies should follow and organize better performance in the country. 
Table 3: Performance of Primary Cooperatives -2016/17

\begin{tabular}{|c|c|c|c|c|c|c|c|c|}
\hline \multirow[b]{2}{*}{ No. } & \multirow{2}{*}{$\begin{array}{l}\text { Cooperative } \\
\text { societies }\end{array}$} & \multirow{2}{*}{$\begin{array}{l}\text { No. of } \\
\text { Cooperative }\end{array}$} & \multicolumn{2}{|c|}{ Member } & \multirow[b]{2}{*}{ Total } & \multirow[b]{2}{*}{ Capital } & \multirow{2}{*}{$\begin{array}{l}\% \text { share } \\
\text { of } \\
\text { capital }\end{array}$} & \multirow{2}{*}{$\begin{array}{l}\text { Capital per } \\
\text { total membe }\end{array}$} \\
\hline & & & Male & Female & & & & \\
\hline 1 & $\begin{array}{l}\text { Multipurpose } \\
\text { agricultural }\end{array}$ & 7168 & 297207 & 1109672 & 47813442 & 753556344 & 75.09 & 15.76 \\
\hline 2 & $\begin{array}{l}\text { Forestry } \\
\text { development }\end{array}$ & 120 & 8064 & 1556 & 9295 & 1929859 & 0.19 & 207.6 \\
\hline 3 & $\begin{array}{l}\text { Fruit and } \\
\text { vegetable }\end{array}$ & 117 & 3805 & 913 & 4720 & 1631238 & 0.16 & 345.6 \\
\hline 4 & Gum and inset & 33 & 1934 & 227 & 2161 & 8942365 & 0.89 & 4138.07 \\
\hline 5 & Irrigation & 1116 & 69034 & 12780 & 81638 & 3466734 & 3.42 & 420.97 \\
\hline 6 & Dairy & 335 & 13017 & 7761 & 20778 & 183751106 & 18.31 & 8843.5 \\
\hline 7 & Fishery & 55 & 3240 & 353 & 3493 & 4404284 & 0.44 & 1260.9 \\
\hline 8 & Honey & 91 & 10873 & 1026 & 11899 & 5203870 & 0.52 & 437.34 \\
\hline 9 & Coffee & 43 & 2707 & 335 & 3042 & 5609971 & 0.56 & 1844.2 \\
\hline 10 & Livestock & 840 & 25426 & 9371 & 3471 & 9216316 & 0.92 & 265.25 \\
\hline \multirow[t]{2}{*}{11} & Chat & 1 & 104 & - & 104 & 9660 & 0.01 & 92.9 \\
\hline & Total & 9919 & 3110211 & 1143994 & 425425 & 1003572293 & $100 \%$ & 235.9 \\
\hline
\end{tabular}

Source: Federal Cooperative Commission 2016/17

Table 4. Secondary Cooperative Performance

\begin{tabular}{lllllll} 
No. & Cooperative union type & $\begin{array}{l}\text { No. of } \\
\text { cooperative }\end{array}$ & Member & Capital Birr & $\begin{array}{l}\text { \% share of } \\
\text { capital }\end{array}$ & $\begin{array}{l}\text { Capital per } \\
\text { member }\end{array}$ \\
\hline 1 & Grain and marketing & 122 & 3392 & 4000253132 & 65.97 & 117999.15 \\
2 & Dairy product & 6 & 73 & 3634752 & 0.60 & 49791.12 \\
3 & Honey & 2 & 15 & 340047 & 0.06 & 22669.8 \\
4 & Coffee & 10 & 467 & 130070734 & 21.34 & 280324.9 \\
5 & Forestry & 2 & 13 & 371615 & 0.06 & 28585.8 \\
6 & Animal & 3 & 24 & 856366 & 0.14 & 35681.92 \\
7 & Vegetable and fruit & 6 & 146 & 73999347 & 12.14 & 506844.8 \\
\hline Total & & 151 & 4130 & 60952993 & $100 \%$ & 4036595.98 \\
\hline
\end{tabular}

Source: Federal Cooperative Commission (2011/12-2016/17)

\section{Conclusions and Recommendations}

Organization and administration of cooperative societies in Ethiopia have suffered in the past and present state especially in rural areas. But initiation by FDRE of the country in recent socio-economic transformation are well organized way and new establishments are with special market economic principles. Most of the members of the cooperatives are using domestic seeds rather than import form foreign countries because of the active and efficient function of cooperatives in the country. Cooperatives represent more than $85 \%$ of the total input supply to the public and the price drop to the public through competitive order on average 10-15\%. Cooperatives output marketing depends upon the income of the local community. Hence the cooperatives working as a market intermediation in the home marketing by supplying the agricultural output among community in the country. The cooperatives of the country contribute meaningful employment opportunity and poverty alleviation in the country in the last ten years. Hence, the government and stakeholders have to conscious to promote the cooperatives.Primary and secondary cooperatives undertaking countless work among the members and their capital accumulation is outstanding in the nation. Hence, the government and stakeholders have to be sensible to encourage the cooperatives.

There is still lack of awareness about cooperatives among stakeholders, policy makers and even community people. Hence government and stakeholders have to expose to successful practice of the cooperatives in the country. There is poor linkage among cooperatives, government, private, agroprocessing plants and financial institutions because of the lack of linkage among institutions, import from other countries happening, so there must be collective effort should be taken to promote the cooperatives in the country. The cooperatives are not getting proper 
legal support from government and NGOs because of that the cooperatives in Ethiopia indulge in taxes for their economic activities. Hence, exports from the cooperatives are limited in the country. Bargain power of cooperatives has increased through healthy function of the organization. Still middle men intermediation exists in procurement and marketing of agricultural commodities and these kinds of illegal activities eliminate by the government's severe action. Training and education of the community will increase their sustainable and economic improvement of life.

The cooperatives of the country have deficiency of these activities among the people. Thus, cooperatives should concentrate on the training and education to firstly their members and secondly to the public. Cooperatives are economic foundations and it plays a key role in food safety and poverty alleviation of the country. Hence government is essential to devote to launch marketing and financial services with the training and education, to support the cooperative program.

\section{References}

[1]. Iyasu, (2004), Report on the Ethiopian Economy, vol. III, Addis Ababa. Ethiopia.

[2]. Nuredin Mohammed1, Byeong Wan Lee (2015) "Role of Cooperatives in Rural Development, the Case of South Nations Nationalities and People Region, Ethiopia" Science Journal of Business and Management. 3(4): P102-108.

[3]. Dejen Debeb and Matthews Haile (2016) "Agricultural Cooperatives, Opportunities and Challenges, the Case of Bench Maji Zone, Ethiopia" Journal of Poverty, Investment and Development. 22. P57-69.

[4]. Musa Hasen Ahmed and Hiwot Mekonnen Mesfin (2017) "The Impact of Agricultural Cooperatives Membership on The Wellbeing of Smallholder Farmers: Empirical Evidence from Eastern Ethiopia" Agricultural and Food Economics. 5(6): P1-20.

[5]. Dagne Mojo, Terefe Degefa and Christian Fischer (2017) "The Development of Agricultural Cooperatives in Ethiopia: History and a Framework for Future Trajectory" EJOSSAH Vol. XIII, No.1. P49-77.

[6]. Delelegne A. Tefera, Jos Bijman1 and Maja A. Slingerland. (2017) "Agricultural CoOperatives in Ethiopia: Evolution, Functions and Impact" Journal of International Development. 29, P431-453.

[7]. Eshetie Berhan Atanaw and Sisay Geremew Gebeyehu. (2019) "The Role of Cooperatives on the Socio-economic Development of Ethiopia" Journal of Management Research. 119(1). 